\title{
Combined effects of salinity and temperature on juvenile survival, growth and maturation in the polychaete Hydroides elegans
}

\author{
Jian-Wen Qiu*, Pei-Yuan Qian \\ Department of Biology, The Hong Kong University of Science and Technology, Clear Water Bay, Kowloon, Hong Kong
}

\begin{abstract}
Effects of salinity $\left(15\right.$ to $\left.35^{\circ} \%\right)$ and temperature $\left(15\right.$ to $\left.30^{\circ} \mathrm{C}\right)$ on the survival and growth of juvenile polychaete Hydroides elegans (Haswell), and on their subsequent reproduction, were examined in 2 laboratory experiments. Within the experimental range, temperature did not influence survivorship. However, low salinity reduced survivorship: at $15 \%$, all juveniles died within $8 \mathrm{~d}$; at $20 \%$, about $30 \%$ of the individuals died within $8 \mathrm{~d}$, but almost all remaining individuals survived throughout the following $17 \mathrm{~d}$ of the experiment. At higher salinities, over $95 \%$ of the individuals survived throughout the experiment. Juveniles were more vulnerable to low salinity $(20 \%)$ within $1 \mathrm{~d}$ of settlement than at older ages. Both low temperature and low salinity led to slower growth and subsequently to a longer time to maturation. At $\geq 25 \%$ and $\geq 20^{\circ} \mathrm{C}$, first spawning occurred on Day 16 of the experiment. More treatments were found to have mature worms on Day 25 than on Day 16 of the experiment. Tubes of reproductive individuals were usually longer than $1.2 \mathrm{~cm}$. The male to female ratio varied among treatments from 025 to 30 and anneared to be independent of salinity and temperature conditions. Average fecundity ranged from 1100 to 9050 oocytes per female and seemed unaffected by temperature Average fecundity was similar at salinities $\geq 25 \%$ but was lower at the lowest survival salinity $(20 \%$ ). This is the first study to report on growth and maturation of $H$. elegans under controlled laboratory conditions. It provides information to explain the settlement and population changes of this species in the field. The results also support the ideas that early developmental stages are more sensitive to environmental stress than late juveniles and adults, and that juveniles are most vulnerable at the onset of benthic life.
\end{abstract}

KEY WORDS: Polychaete · Hydroides - Growth Fecundity - Maturation - Salinity - Temperature

\section{INTRODUCTION}

Experiments using the early life stages of Hydroides elegans (Qiu \& Qian 1997) suggest that low salinity in summer could limit embryonic and larval development, and eventually suppress the recruitment of this species in Hong Kong waters. However, in addition to the embryonic and larval stages, the juvenile period is often a critical stage where heavy mortality occurs. Such high mortality is especially evident at the onset of juvenile life due to vulnerability to stresses such as predation, competition, desiccation, low salinity, and deposition of sediment (Gosselin \& Qian 1997). Furthermore, being able to grow under stress does not guarantee a population's reproductive success, as nor-

•E-mail: bojwqiu@ust.hk mal sexual development may require less stressful conditions (Nias et al. 1993).

This study follows on from Qiu \& Qian (1997) to test the developmental sensitivity of juvenile Hydroides elegans to salinity and temperature and to determine if the results support the hypothesis that field settlement patterns can be explained by the sensitivity of life-history traits to environmental stress. Since the juveniles of $H$. elegans are well adapted to food limitation (they can survive in $0.22 \mu \mathrm{m}$ filtered seawater for $>20 \mathrm{~d}$; Qian et al. unpubl. data), this study focused on the sensitivity of juvenile survival, growth, and reproductive parameters (i.e. whether stressed conditions will lead to unbalanced sex ratio, decreased oacyte production or delayed reproduction) to salinity and temperature, 2 important environmental factors that exhibit seasonal changes in Hong Kong. 


\section{MATERIALS AND METHODS}

Rearing procedures. Juveniles were developed from gametes fertilized in the laboratory in April (Expt I) and August (Expt II) 1997 Procedures for fertilization and larval culture were adopted from Hadfield et al. (1994) and described in Qiu \& Qian (1997). Competent larvae were induced to settle in Petri dishes (diameter $5 \mathrm{~cm}$ ) using $10^{5}$ cells $\mathrm{ml}^{-1}$ Isochrysis galbana as food and the leachate of the bryozoan Bugula neritina, which has been shown to effectively induce $H$. elegans larvae to settle (Bryan et al. 1998). In each dish, 25 to 40 out of 100 larvae metamorphosed within $24 \mathrm{~h}$. Larvae that did not metamorphose within $24 \mathrm{~h}$ were decanted. Juveniles settling too close to each other and excess juveniles were scraped off, leaving only 15 to 20 individuals per dish in Expt I and 15 to 30 in Expt II. The setup of the 2 experiments is detailed below.

Expt I: Metamorphosis to maturation. Expt I, commenced on 21 April 1997, was designed to examine how salinity and temperature affect survival, growth and maturation of newly metamorphosed juveniles. The experimental ranges of salinity (15 to $35 \%$ ) and temperature $\left(15\right.$ to $\left.30^{\circ} \mathrm{C}\right)$ were comparable to those encountered in the eastern part of Hong Kong waters (EPD 1996). The setup followed a 2 -factor design, using 4 temperature levels $\left(15,20,25,30^{\circ} \mathrm{C}\right)$ and 5 salinity levels $(15,20,25,30,35 \%)$ for a total of 20 treatments. Salinities were obtained by diluting artificial seawater $(35 \%)$ with deionized water. Each of the 20 treatments consisted of 3 replicate dishes, each containing 15 to 20 juveniles that had metamorphosed within the previous $24 \mathrm{~h}$. Each Petri dish was tied to a plastic net (mesh size: $1 \times 1 \mathrm{~cm}$ ) and placed in a polyethylene beaker containing 1.81 seawater. $A$ total of 943 juveniles with an average initial tube length of $0.65 \pm 0.12 \mathrm{~mm}(\mathrm{n}=30)$ were used. The beakers were placed in biological incubators (Powers Scientific SD33SE) at the 4 designated temperatures. During the experiment, seawater was changed every $3 \mathrm{~d}$ and Isochrysis galbana was added to the cultures daily to obtain an initial concentration of $2 \times 10^{5}$ cells $\mathrm{ml}^{-1}$.

On the 8th day of the experiment, the number of survivors in each of the dishes was counted and the lengths of the survivors were measured. Since the shape of a Hydroides elegans tube is often irregular, direct length measurement under a microscope is impossible. Therefore, $H$. elegans tubes were recorded using a video camera mounted on a dissecting microscope (magnification: 6.3×) (Qian \& Pechenik in press). Tube images were then digitized and lengths were measured using an image analysis software (Optimas 5.2). A preliminary study showed that under ample food conditions, $H$. elegans matured in about 2 wk post-settlement. Therefore, starting from Day 10 of the experiment, cultures were checked daily for mature worms by filtering about $1 \mathrm{l}$ culture medium from each beaker through a $25 \mu \mathrm{m}$ mesh. Any oocyte, embryo, or larva retained on the mesh would indicate spawning within the last $24 \mathrm{~h}$. When the first spawning occurred on the 16th day of the experiment, survivors in all dishes were enumerated. Tubes of the survivors were video recorded, then the worms in 1 of the 3 replicates were detached and placed individually in Petri dishes containing $10 \mathrm{ml}$ seawater to examine reproductive status. Individuals not releasing gametes and those releasing sperm and oocytes were recorded and the number of oocytes produced by each female (fecundity) was enumerated. Since, on Day 16 , mature worms were found only at $\geq 25 \%$ salinity and $\geq 20^{\circ} \mathrm{C}$, other treatments were chcckcd daily until mature worms were found at the lowest temperature $\left(15^{\circ} \mathrm{C}\right)$ This happened on Day 25, at which time the experiment was terminated. Survivors in the 2 remaining dishes in each treatment were counted, their tubes were video recorded, and they were then detached to determine reproductive status.

Expt II: Age-dependent tolerance to low salinity. Expt I revealed that at $20 \%$ salinity, about $30 \%$ of the worms died within the first $8 \mathrm{~d}$ of the experiment, but afterwards virtually all remaining individuals survived to the termination of the experiment (Day 25). This suggests that younger juveniles may be more vulnerable to low salini:y than older juveniles. Alternatively, the lower mortality after the first $8 \mathrm{~d}$ of Expt I might be due to acclimation of juveniles to low salinity. Therefore, a second experiment, commenced on 10 August 1997, was conducted to test whether age is a determining factor in the vulnerability to low salinity in juvenile Hydroides elegans. $H$. elegans competent larvae began metamorphosing at $6 \mathrm{~h}$ and reached a peak about 10 to $14 \mathrm{~h}$ after introduction into Bugula neritina leachate. At 24 h, larvae that had not metamorphosed were decanted by transferring dishes into new culture media containing no larvae. At $36 \mathrm{~h}$, juveniles were used for the salinity tolerance experiment and aged as $1 \mathrm{~d}$ old for convenience, although they represented juveniles which had metamorphosed for 12 to $30 \mathrm{~h}$. Juveniles of other ages (2 to $10 \mathrm{~d})$ were obtained by rearing the same batch of juveniles at $35 \%$ salinity, $25^{\circ} \mathrm{C}$, and $10^{5}$ cells $\mathrm{ml}^{-1}$ Isochrysis galbana until the day of the experiment. Petri dishes (diameter $5 \mathrm{~cm}$ ) containing 1,2, 5, and $10 \mathrm{~d}$ old juveniles were each placed in a beaker containing $0.6 \mathrm{l}$ seawater (salinity: 15,20 , and $35 \%$ ) and I. galbana at a concentration of $10^{5}$ cells $\mathrm{ml}^{-1}$ (3 replicates/treatment, each containing 15 to 30 individuals). Different salinities were obtained by diluting 
artificial seawater $(35 \%)$ with deionized water. The 4 groups of juveniles of different ages ( 1 to $10 \mathrm{~d}$ old) were each maintained for $10 \mathrm{~d}$ at $25^{\circ} \mathrm{C}$. The media were replaced, and survival of juveniles was checked every $2 d$.

Statistical analysis. Data were analyzed by parametric statistical analysis unless the normality assumptions of parametric analysis (Shapiro \& Wilk test, in Zar 1984, p 95) were not met. In those cases, nonparametric analyses (Conover \& Iman 1981, p 124-129; SAS 1988, p 293-297) were performed by transforming values to ranks before performing parametric statistical analyses (Zar 1984, p 206-217). The Tukey multiple comparisons test ( $Z$ ar 1984, p 186-190) was used to compare treatment means in cases where factors did not significantly interact. During the experiment, 1 of the 3 replicates was sampled destructively for reproductive status and fecundity determination on Day 16 , leaving another 2 replicates for Day 25. However, in 1 of the 2 replicates left, 3 treatments $\left(25^{\circ} \mathrm{C}\right.$ and $30 \%$, $25^{\circ} \mathrm{C}$ and $35 \%, 30^{\circ} \mathrm{C}$ and $30 \%$ ) contained multi-cell or blastula stages when checked at Day 25. The spawning of a few individuals in these beakers seemed complete, making it likely that some 'immature' worms might actually be post-spawning ones. To avoid confusion, reproductive data for this third replicate were not collected. Since the data for Day 16 and Day 25 were each from only 1 replicate, quantitative statistical analyses (2-way ANOVA without replication) were not performed because of the lack of power inherent to the test.

\section{RESULTS}

\section{Expt I: Metamorphosis to maturation}

\section{Survival}

Survivorship was independent of temperature (15 to $30^{\circ} \mathrm{C}$ ) but was greatly influenced by salinity (15 to $35 \%$ ) (Fig. 1, Table 1): at 15\%, all juveniles died within $8 \mathrm{~d}$ of exposure; at $20 \%$ about $30 \%$ of the individuals died within the first $8 \mathrm{~d}$ of the experiment, and afterwards virtually no further mortality occurred; at $\geq 25 \%$ salinity, over $95 \%$ of the individuals survived throughout the experiment. No interaction between temperature and salinity on survivorship was detected (Fig. 1, Table 1).

\section{Increase in tube length}

The overall average growth in tube length in the 16 treatments (worms in the 15\% salinity treatments had all died) ranged from 0.19 to $1.01 \mathrm{~mm} \mathrm{~d}^{-1}$. Tube growth seemed faster during Days 1 to $8\left(0.82 \pm 0.31 \mathrm{~mm} \mathrm{~d}^{-1}\right)$ than during Days 8 to $16\left(0.62 \pm 0.34 \mathrm{~mm} \mathrm{~d}^{-1}\right)$ and Days 16 to $25\left(0.66 \pm 0.40 \mathrm{~mm} \mathrm{~d}^{-1}\right)$. At the end of the experiment, tube lengths had reached 0.5 to $2.5 \mathrm{~cm}$. Increase in tube length was affected by both temperature and salinity (Fig. 2, Table 1) and a significant interaction between temperature and salinity was detected on Day 8 and Day 16 (Table 1), with the slowest growth occurring at the lowest salinity and temperature treatment and the fastest growth in the highest salinity and temperature treatment (Fig. 2).

\section{Reproductive traits}

First spawning occurred on Day 16, at which time mature worms were found at salinities $\geq 25 \%$ and temperatures $\geq 20^{\circ} \mathrm{C}$ (Fig. 2, Table 2). Within a given treatment, maturation seemed relatively synchronized: when a treatment had mature worms, the percentages of mature worms ranged from 35 to $56 \%$. On Day 25 , mature worms were found in all treatments except at $20 \%$ salinity and $20{ }^{\circ} \mathrm{C}$, and 20 to $30 \%$ salinity and $15^{\circ} \mathrm{C}$ (Fig. 2, Table 2). Compared with Day 16, both the number of treatments having mature worms ( 8 vs 12) and the percentage of mature worms $(46.6 \pm 7.5$ vs 62.4 \pm 15.3 ) were higher on Day 25. The male to female ratio varied among treatments from 0.25 to 3.0 and seemed to be unrelated to salinity and temperature (Table 2). Within each treatment, the number of oocytes released per female varied dramatically among females. Average fecundity among the treatments ranged from 1100 to 9050 . Fecundity seemed unaffected by temperature but was lowest at the lowest survival salinity (20\%) (Table 2). Reproduction occurred usually when an individual exceeded $1.2 \mathrm{~cm}$ in tube length.

\section{Expt II: Age-dependent tolerance to low salinity}

This second experiment was designed to test the tolerance of juvenile ( 1 to $10 \mathrm{~d}$ old) Hydroides elegans to low salinity. At ages of 2, 5, and $10 \mathrm{~d}$, juveniles responded similarly to salinity treatments (Fig. 3): at $15 \%$, all individuals died within $2 \mathrm{~d}$; at $\geq 20 \%$, over $95 \%$ of individuals survived to the end of the $10 \mathrm{~d}$ experiment. The $1 \mathrm{~d}$ old juveniles responded to 15 and $35 \%$ salinities similarly to older juveniles, in that all died at $15 \%$ within $2 \mathrm{~d}$, whereas most survived at $35 \%$. At $20 \%$ salinity, however, the 1 d old juveniles suffered about $25 \%$ mortality within $2 \mathrm{~d}$, being significantly higher than mortality of older juveniles $(0$ to $3.5 \%)$ (Fig 3). 


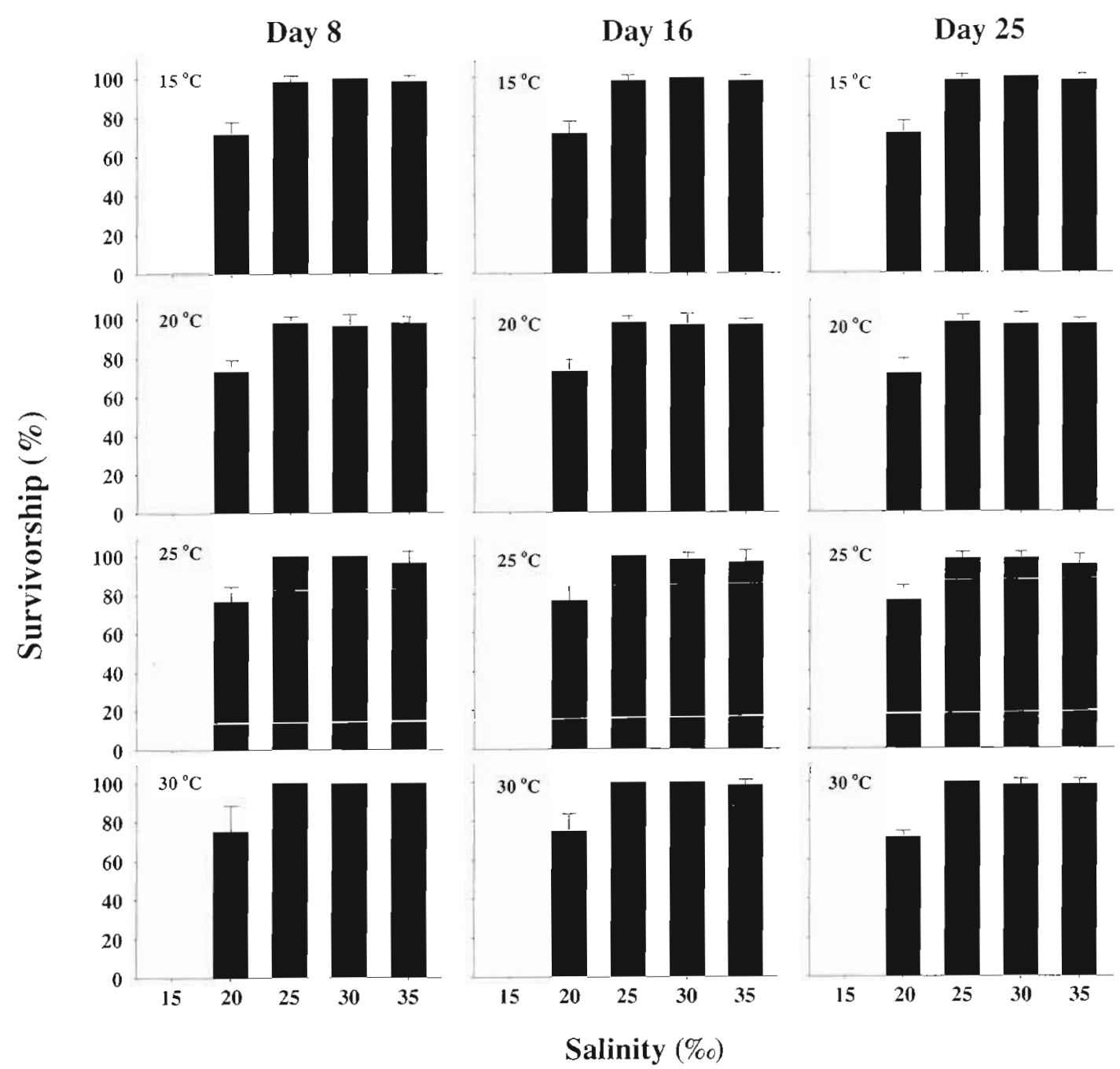

Fig. 1. Hydroides elegans. Expt I: Effects of salinity and temperature on juvenile survival. Data are plotted as the mean survivorship of 3 (Day 8 and Day 16) or 2 (Day 25) replicates + standard deviation in each treatment. All juveniles at $15 \%$ had died when checked on Day 8 of the experiment

\section{DISCUSSION}

This study focused on the effects of salinity and temperature on the juvenile stage of Hydroides elegans. We found that salinity exerted a significant influence on juvenile survivorship, growth and maturation (Fig. 1): juvenile survival was threatened when salinities were $\leq 20 \%$; and the sensitivity to $20 \%$ salinity was not altered by adaptation but was age-related: $1 \mathrm{~d}$ old juveniles (a mixture of juveniles 12 to $30 \mathrm{~h}$ post metamorphosis) suffered a $\sim 25 \%$ mortality while less than $5 \%$ of $\geq 2$ d old juveniles died during Expt II. It is likely that the $-25 \%$ mortality in $1 \mathrm{~d}$ old juveniles could be due to nearly $100 \%$ survival of those juveniles that settled earlier combined with $0 \%$ survival of those metamorphosed later. Experiments using juveniles with more uniform timing of metamorphosis should allow us to better determine the mortality source of the ' $1 \mathrm{~d}$ old' juveniles (Dr B. Hentschel pers. comm.).

In a few decapods, metamorphosis seems to mark a dramatic change in osmoregulation. Premetamorphic stages that are hyperosmoconforming or weakly hyperosmoregulating over a wide range of salinities undergo a change to become adults which are either (a) strongly hyperosmoregulating in low salinity and osmoconforming in high salinity, or (b) hyper-hypoosmoregulating (Brown \& Terwilliger 1992, p 274). In juvenile Hydroides elegans, the physiological or biological changes corresponding to the change in resistance to low salinity is unknown. Since juveniles $\geq 2 \mathrm{~d}$ old have similar tolerance levels to low salinity which is stronger than in the $1 \mathrm{~d}$ old juveniles, this species may develop its osmoregulating mechanism during the first day post metamorphosis. 
Compared with earlier stages, juveniles and adults were more resistant to low salinity [critical salinity for embryonic stages: 25 to 30\%。 (Qiu \& Qian 1997); larval stage: 20 to 25\% (Qiu \& Qian 1997); juveniles and adults: 15 to $20 \%$ (this study)]. These results support the ideas that early developmental stages are more sensitive than juveniles and adults to environmental stress, and that juveniles are most vulnerable at the onset of juvenile life (Gosselin \& Qian 1997). In Hong Kong waters, when salinity drops during the summer monsoon, the reproduction of Hydroides elegans in the surface water may be adversely affected. Those in deeper water, where salinity drops less dramatically
(Morton \& Morton 1983, EPD 1996), may still grow and reproduce. However, since embryonic development is more sensitive to low salinity, any zygotes produced in the summer will still not be able to complete larval development if they swim up to the surface, especially the most vulnerable swimming blastula stage $(100 \%$ mortality at $\leq 25 \%$ salinity).

Juvenile survivorship was also independent of temperature $\left(15\right.$ to $30^{\circ} \mathrm{C}$ ) (Fig. 1). Although juveniles grew considerably slower in the lower temperature and salinity treatments, those in the $15^{\circ} \mathrm{C}$ and $35 \%$ treatment did eventually reach maturity (Fig. 2). At $15^{\circ} \mathrm{C}$. fecundity of the worms was lower than that of the

Table 1. Hydroides elegans. Summary of 2-way ANOVA results on effects of temperature and salinity on survival and growth. All the data, except the daily tube length increment data for Day 25 which were normally distributed (Shapiro-Wilk test, $W=0.0572$ ), were ranked before ANOVA tests were performed. Survival is expressed as percentage of survivors, whereas growth is expressed as average daily tube length increment between 2 successive measurements. There were 3 replicates on Day 8 and Day 16, but only 2 replicates on Day 25 of the experiment. Each replicate started with 15 to 20 individuals. When there were no interactions between factors, Tukey tests were performed. Values that do not differ at 0.05 level are indicated by the same letter following the corresponding salinity or temperature levels. ns: not significant. na: data not available due to mortality of entire treatment. Note that data collected on later dates are not independent of those collected on earlier dates

\begin{tabular}{|c|c|c|c|c|c|c|c|c|}
\hline & \multicolumn{5}{|c|}{ Treatments } & $\mathrm{df}$ & $F$ & $\mathrm{p}$ \\
\hline \multicolumn{9}{|l|}{ Day 8} \\
\hline \multicolumn{9}{|l|}{ Survivorship } \\
\hline Salinity (\%) & $35(\mathrm{~A})$ & $30(\mathrm{~A})$ & $25(\mathrm{~A})$ & $20(B)$ & $15(C)$ & 4 & 93.94 & 0.0001 \\
\hline Teñperatiue $\left({ }^{\circ} \mathrm{C}\right)$ & $30(\hat{A})$ & $25(\hat{A})$ & $20(\hat{A})$ & $15\{\hat{A}\}$ & & 3 & 1.01 & 0.3069 (ns) \\
\hline Salinity $\times$ Temperature & & & & & & 12 & 0.41 & 0.9505 (ns) \\
\hline Error & & & & & & 40 & & \\
\hline \multicolumn{9}{|l|}{ Daily tube length increment } \\
\hline Salinity (\%o) & 35 & 30 & 25 & 20 & na & 3 & 94.07 & 0.0001 \\
\hline Temperature $\left({ }^{\circ} \mathrm{C}\right)$ & 30 & 25 & 20 & 15 & & 3 & 136.6 & 0.0001 \\
\hline Salinity $\times$ Temperature & & & & & & 9 & 7.91 & 0.0001 \\
\hline Error & & & & & & 32 & & \\
\hline \multicolumn{9}{|l|}{ Day 16} \\
\hline \multicolumn{9}{|l|}{ Survivorship } \\
\hline Salinity (\%a) & $35(\mathrm{~A})$ & $30(\mathrm{~A})$ & $25(\mathrm{~A})$ & $20(\mathrm{~A})$ & & 3 & 0.64 & 0.5948 (ns) \\
\hline Temperature $\left({ }^{\circ} \mathrm{C}\right)$ & $30(\mathrm{~A})$ & $25(\mathrm{~A})$ & $20(\mathrm{~A})$ & $15(\mathrm{~A})$ & & 3 & 0.69 & 0.5623 (ns) \\
\hline Salinity $\times$ Temperature & & & & & & 9 & 0.89 & 0.5454 (ns) \\
\hline Error & & & & & & 32 & & \\
\hline \multicolumn{9}{|l|}{ Daily tube length increment } \\
\hline Salinity (\%) & 35 & 30 & 25 & 20 & & 3 & 58.86 & 0.0001 \\
\hline Temperature $\left({ }^{\circ} \mathrm{C}\right)$ & 30 & 25 & 20 & 15 & & 3 & 24.55 & 0.0001 \\
\hline Salinity $\times$ Temperature & & & & & & 9 & 7.66 & 0.0001 \\
\hline Error & & & & & & 32 & & \\
\hline \multicolumn{9}{|l|}{ Day 25} \\
\hline \multicolumn{9}{|l|}{ Survivorship } \\
\hline Salinity $(\%)$ & $35(\mathrm{~A})$ & $30(\mathrm{~A})$ & $25(\mathrm{~A})$ & $20(\mathrm{~A})$ & & 3 & 0.27 & 0.8455 (ns) \\
\hline Temperature $\left({ }^{\circ} \mathrm{C}\right)$ & $30(\mathrm{~A})$ & $25(\mathrm{~A})$ & $20(\mathrm{~A})$ & $15(A)$ & & 3 & 0.71 & 0.5521 (ns) \\
\hline Salinity $\times$ Temperature & & & & & & 9 & 0.91 & 0.5399 (ns) \\
\hline Error & & & & & & 16 & & \\
\hline \multicolumn{9}{|l|}{ Daily tube length increment } \\
\hline Salinity $(\%)$ & $35(\mathrm{AC})$ & $30(\mathrm{AC})$ & $25(\mathrm{AB})$ & $20(\mathrm{C})$ & & 3 & 4.79 & 0.0144 \\
\hline Temperature $\left({ }^{\circ} \mathrm{C}\right)$ & $30(\mathrm{AB})$ & $25(B)$ & $20(\mathrm{AC})$ & $15(C)$ & & 3 & 12.72 & 0.0002 \\
\hline Salinity $\times$ Temperature & & & & & & 9 & 1.24 & 0.3401 (ns) \\
\hline Error & & & & & & 16 & & \\
\hline
\end{tabular}




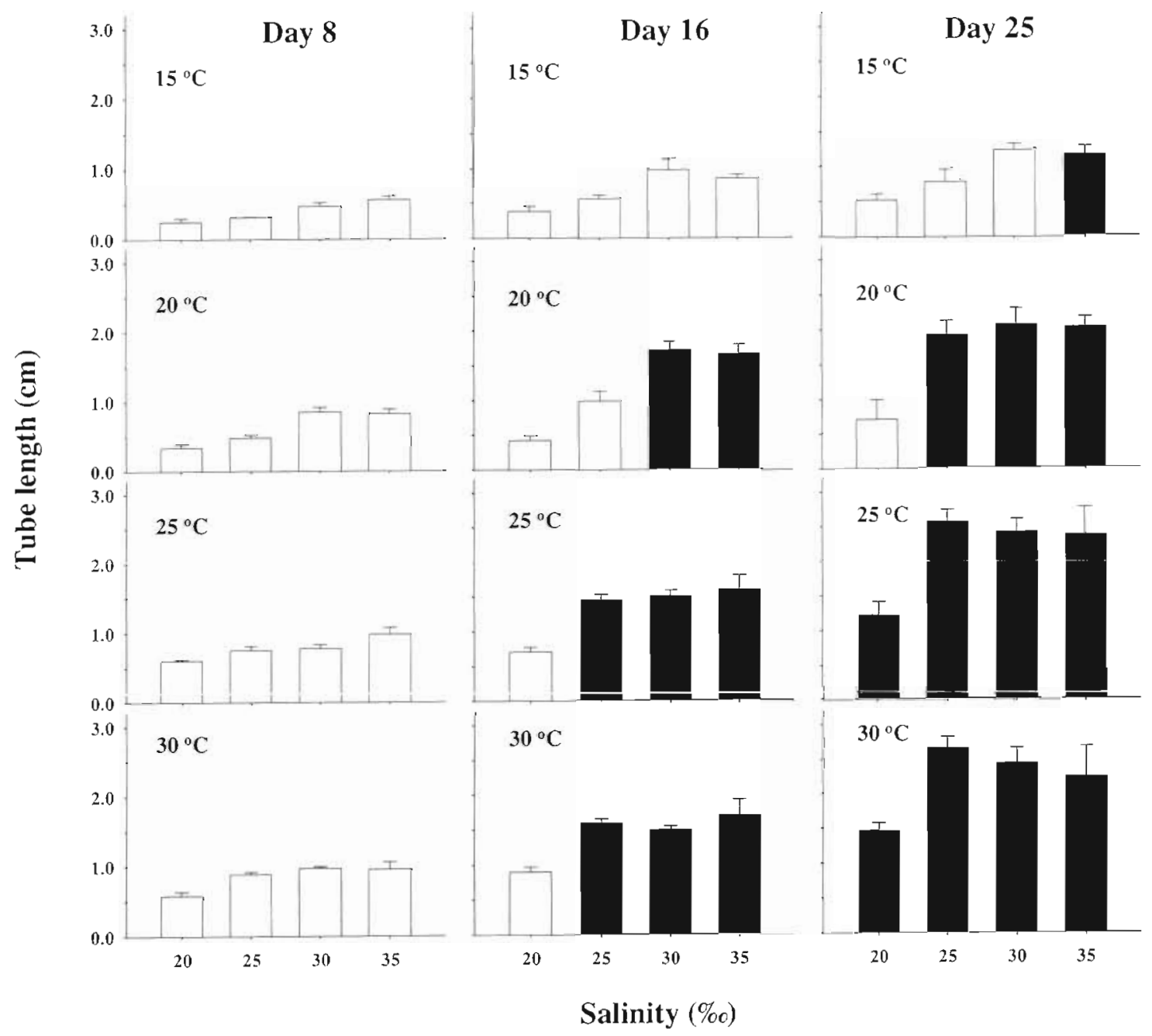

Fig. 2. Hydroides elegans. Expt I: Effects of salinity and temperature on growth (tube length) and age at first reproduction. Data are plotted as the mean tube length of 3 (Day 8 and Day 16) or 2 (Day 25) replicates + standard deviation in each treatment. At the onset of the experiment, each replicate consisted of 15 to 20 individuals. Open bars indicate treatments without reproductive worms, solid bars indicate treatments with reproductive worms

Table 2. Hydroides elegans. Effects of temperature and salinity on reproductive traits. na = not available. Data for Day 16 and Day 25 were each derived from the individuals (starting with 15 to 20 individuals) from 1 of the 3 replicates. The total number of females whose fecundity had been determined was 36 and 68 for Day 16 and Day 25 respectively. For the third replicate, 3 treatments $\left(25^{\circ} \mathrm{C}\right.$ and $30 \%, 25^{\circ} \mathrm{C}$ and $35 \%, 30^{\circ} \mathrm{C}$ and $30 \%$ contained multi-cell or blastula stages when being checked on Day 25 . Since the spawning of a few individuals in these beakers seemed complete, it was likely that some 'immature' worms might actually be post-spawning ones. To avoid confusion, reproductive data for this third replicate were not collected

\begin{tabular}{|c|c|c|c|c|c|c|c|c|c|c|c|c|c|c|c|c|}
\hline \multirow{2}{*}{$\begin{array}{r}\text { Temperature }\left({ }^{\circ} \mathrm{C}\right): \\
\text { Salinity }(\%):\end{array}$} & \multicolumn{4}{|c|}{-30} & \multicolumn{4}{|c|}{-25} & \multicolumn{4}{|c|}{-20} & \multicolumn{4}{|c|}{-15} \\
\hline & 35 & 30 & 25 & 20 & 35 & 30 & 25 & 20 & 35 & 30 & 25 & 20 & 35 & 30 & 25 & 20 \\
\hline \multicolumn{17}{|l|}{ Day 16} \\
\hline Mature $(\%)$ & 50.0 & 56.3 & 41.2 & 0 & 35.3 & 41.2 & 42.9 & 0 & 50.0 & 55.5 & 0 & 0 & 0 & 0 & 0 & 0 \\
\hline Male/female & 0.6 & 1.3 & 1.3 & na & 0.5 & 0.3 & 2.0 & na & 1.7 & 0.3 & na & na & na & na & na & na \\
\hline Oocytes/female $(\times 100)$ & 690 & 71.1 & 90.5 & na & 52.6 & 43.5 & 41.6 & na & 41.1 & 38.4 & na & na & na & na & na & na \\
\hline \multicolumn{17}{|l|}{ Day 25} \\
\hline Mature (\%) & 70.6 & 44.4 & 68.8 & 46.2 & 47.1 & 50.0 & 68.8 & 75.0 & 88.2 & 83.3 & 52.9 & 0 & 52.9 & 0 & 0 & 0 \\
\hline Male/female & 0.5 & 1.7 & 1.8 & 0.5 & 0.6 & 3.0 & 0.8 & 1.3 & 0.5 & 0.2 & 0.5 & na & 2.0 & na & na & na \\
\hline Oocytes/female $(\times 1.00)$ & 37.1 & 33.4 & 35.7 & 15.8 & 45.5 & 32.5 & 32.6 & 11.1 & 26.0 & 4.2 .7 & 16.7 & na & 12.5 & na & na & na \\
\hline
\end{tabular}



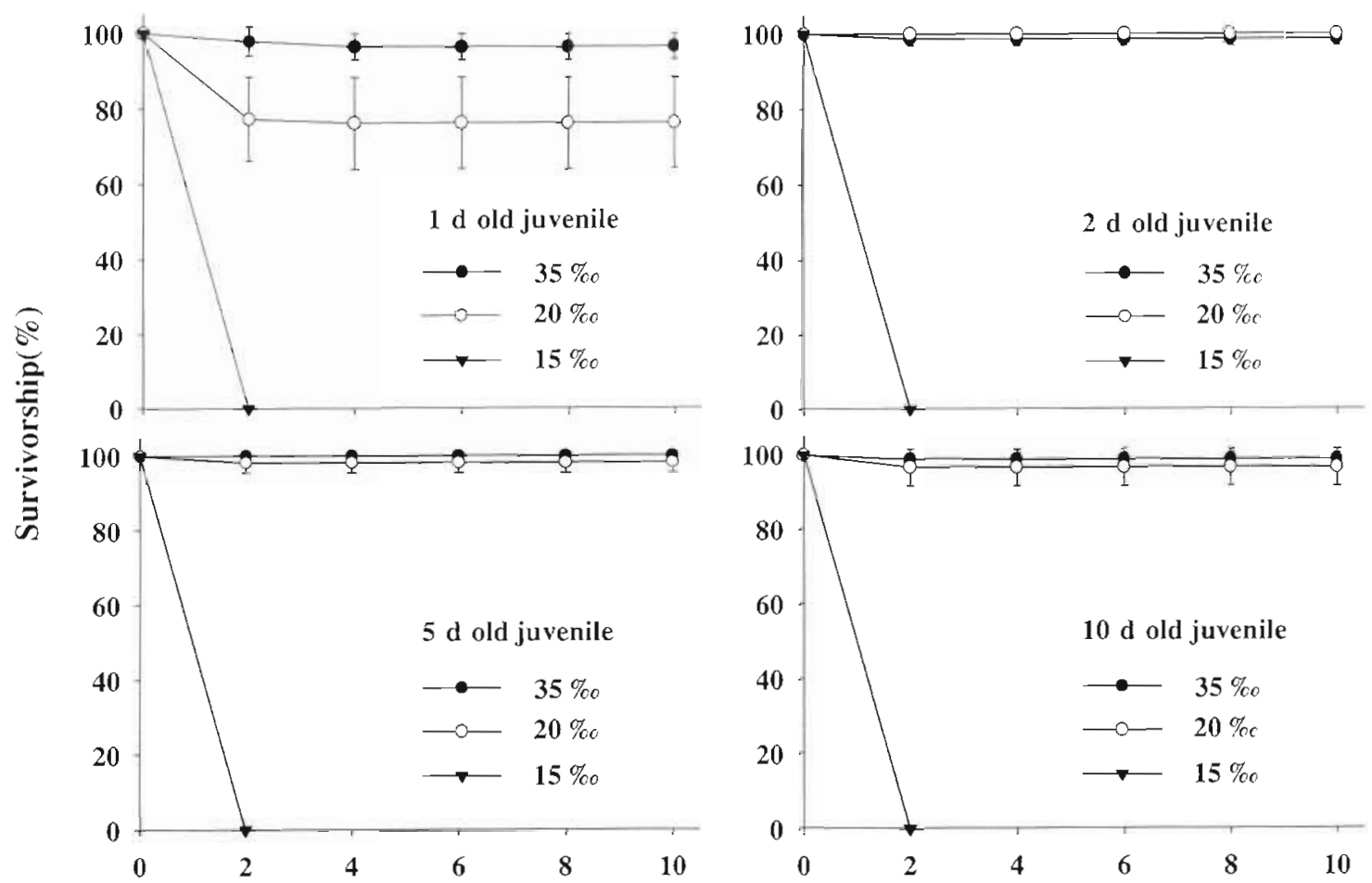

Days in experiment

Fig. 3. Hydroides elegans. Expt II: Effects of salinity and juvenile age on survival. Juveniles of different ages were from the same batch of gametes fertilized in the laboratory. Data are plotted as the mean \pm standard deviation of 3 replicates. At the onset of the experiment, each replicate consisted of 15 to 30 individuals. Survivors were counted every $2 \mathrm{~d}$

worms developed under optimal conditions (Table 2). In Hong Kong waters, however, such low temperature $\left(15^{\circ} \mathrm{C}\right)$ exists only for about half a month (late January or early February). During the remainder of winter and early summer, water temperature remains above $20^{\circ} \mathrm{C}$. The results of this study and those of Qiu \& Qian (1997) suggest that, from winter to early summer, embryonic development, larval development, juvenile development, or maturation leading to successful settlement could occur under the field salinity ( 33 to $35 \%$ ) and temperature $\left(15\right.$ to $\left.25^{\circ} \mathrm{C}\right)$ conditions. Gametes released during the colder months could also develop through fertilization to sexually mature. However, the settlement peaks do not occur until early spring, when phytoplankton concentrations begin to increase (Thompson 1986, Cai 1990), suggesting that phytoplankton may also contribute to the formation of $\mathrm{Hy}$ droides elegans settlement peaks. Although high temperature $\left(30^{\circ} \mathrm{C}\right)$ and high phytoplankton concentration in the summer months may enhance juvenile growth and accelerate maturation, such beneficial effects may be overridden by the detrimental effects of low salinity.

High salinity and temperature favored faster embryonic and larval development (Qiu \& Qian 1997), juvenile growth and shorter time to maturation (this study).
Such conditions exist in some subtropical coastal waters where the influence of the freshwater output from major rivers and rainfall is minor. This may explain the occurrence of settlement peaks in summer or autumn in many places where salinity does not decrease dramatically, but where temperatures may reach about $30^{\circ} \mathrm{C}$ [Port of Lyttleton, New Zealand (Skerman 1958), Sydney, Australia (Wiseley 1958), Los Angeles-Long Beach harbors, USA (Reish 1961), Nagasaki harbor, Japan (Kawahara 1969), Lushun harbor, China (Li et al. 1982), Xisha, China (Zhang et al. 1984)]

It should be noted that in these experiments, all the juveniles were cultured at $35 \%$ prior to being exposed to different salinity and temperature treatments (Expt I) or salinity treatments (Expt II). Although Expt I showed that at a low salinity of $20 \%$, growth and fecundity would be much reduced, given enough time, Hydroides elegans could still reproduce. A question arises whether the embryos developed from gametes derived from adults reared at $20 \%$ are more tolerant to low salinity than are the embryos developed from gametes derived from adults reared at $35 \%$. It presents a possibility that pre-settlement events may affect post-settlement performance. However, if this were 
the case in Hong Kong waters, some larvae would eventually settle and we should have seen some new recruits into the field population during the summer months when salinity is low.

In summary, this is the first report of juvenile growth and maturation of Hydroides elegans, a polychaete species being used frequently in settlement assays to evaluate the anti-settlement capacity of antifouling coatings and natural products. The results of this study, together with Qiu \& Qian (1997), support the ideas that embryonic and larval stages are more sensitive than juveniles and adults to environmental stress, and that juveniles are most vulnerable at the onset of juvenile life. This study also provides supporting evidence for the hypothesis that settlement and population change patterns of $H$. elegans in Hong Kong can be explained by the sensitivity of life-history traits to salinity stress.

Acknowledgements. The authors thank M. G. Hadfield, D. Rittschof and E. Holm for assistance at the initial stage of this study, L. A. Gosselin, S. Lau, B. T Hentschel and 3 anonymous referees for comments and criticisms on the manuscript, L. Soo for technicul support, and $V$. A. Uninefer, K. Bivâdyate añu Johnston for proof reading. This study was supported by 2 grants (CF94/95, SC-17 and HKUST 574/95M) to P.-Y. Qian.

\section{LITERATURE CITED}

Brown AC, Terwilliger NB (1992) Developmental changes in ionic and osmotic regulation in the Dungeness crab, Cancer magister. Biol Bull 182:270-277

Bryan PJ, Kreider JL, Qian PY (1998) Settlement of the serpulid polychaete Hydroides elegans (Haswell) on the arborescent bryozoan Bugula neritina (L.): evidence of a chemically mediated relationship. J Exp Mar Biol Ecol 220:171-190

Cai BJ (1990) Planktonic larvae in Daya Bay. In: Third Institute of Oceanography, State Oceanic Administration (ed) Collections of papers on marine ecology in Daya Bay (II). Ocean Press, Beijing, p 232-236 (in Chinese)

Conover WJ, Iman RL (1981) Rank transformations as a bridge between parametric and nonparametric statistics. Am Statist 25(3):124-129

Editorial responsibility: Otto Kinne (Editor), Oldendorf/Luhe, Germany
EPD (Environmental Protection Department) (1996) Marine water quality in Hong Kong for 1995. Hong Kong Government, Hong Kong

Gosselin L, Qian PY (1997) Juvenile mortality in benthic marine invertebrates. Mar Ecol Prog Ser 146:265-282

Hadfield MG, Unabia CC, Smith CM, Michael TM (1994) Seltlement preferences of the ubiquitous fouler Hydroides elegans. In: Thompson MF, Nagabhushanam R, Sarojini R, Fingerman $M$ (eds) Recent developments in biofouling control. AA Balkema, Rotterdam, p 65-74

Kawahara T (1969) Studies on the marine fouling communities, IV. Differences in the constitution of fouling communities according to localities a. Nagasaki harbour. Rep Fac Fish Prefect Univ Mie 6(3):109-126

Li CY, Huang ZG, Zhang LX, Li FR, Zhen CX, Zhou NQ, Sun LC, Luan RX (1982) Research on the fouling organisms in Lushun harbor. Acta Ecol Sin 2(1):58-65 (in Chinese with English abstract)

Morton J, Morton B (1983) The sea shore ecology of Hong Kong. Hong Kong University Press, Hong Kong

Nias DJ, Mckillup SC, Edyvane KS (1993) Imposex in Lepsiella vinosa from southern Australia. Mar Poilut Buli 2617): $380-384$

Qian PY, Pechenik JA (in press) Effects of delayed metamorphosis and starvation on post-metamorphosis growth and survival in the tube-dwelling polychaete Hydroides eleyarıs. J Exp ivía Divì Ecoì

Qiu JW, Qian PY (1997) Combined effects of salinity, temperature and food on early development of the polychaete Hydroides elegans. Mar Ecol Prog Ser 152:79-88

Reish D (1961) The relationship of temperature and dissolved oxygen to the seasonal settlement of the polychaetous annelid Hydroides norvegica (Gunnerus). Bull Sth Calif Acad Sci 60(A): 1-11

SAS (1988) SAS/STAT user's guide, release 6.03 edn. SAS Institute Inc, Cary, NC

Skerman TM (1958) Marine fouling at the port of Lyttleton. NZ J Sci 1:224-257

Thompson GB (1986) The 1976/77 phytoplankton cycle in Aberdeen Harbor, Hong Kong. Asian Mar Biol 3:33-45

Wisely $B$ (1958) The development and settling of a serpulid worm, Hydroides norvegica Gunnerus (Polychaeta). Aust J Mar Freshwat Res 9:351-361

Zar JH (1984) Biostatistical analysis, 2nd edn. Prentice Hall, Englewood Cliffs, NJ

Zhang LX, Huang ZG, LI CY, Zheng CX (1984) Ecological study on the fouling organisms in Xisha. Acta Oceanol Sin Suppl 5:847-858 (in Chinese)

Submitted: December 16, 1997; Accepted: May 26, 1998 Proofs received from author(s): June 29, 1998 